physiology and classification, we look upon this edition of the Elements, combined with School Botany, as among the best works which he can procure.

\title{
Illustrations of British Mycology. By Mrs. T. I. Hussey. Reeve, Brothers. 4to. Parts 1 \& 2.
}

There is perhaps no country in which so little use is made of the various esculent fungi which abound everywhere in early autumn, as Great Britain. There is no doubt that we have some fifty or sixty species which would afford wholesome and agreeable food, and yet scarcely more than a tenth of this number are ever admitted to our tables. This perhaps is in some measure owing to the circumstance that no British work on esculent fungi, as far as we are aware of, has ever appeared, except the little treatise entitled the 'Mushroom and Champignon' illustrated, which is confined to a very few species. This desideratum is now supplied by the more general work of Dr. Badham, and by the 'Illustrations of British Mycology' now in progress, which bids fair to be one of the most important that has ever appeared on useful and noxious fungi. The illustrations are preceded by a general sketch of fungi founded on the concluding volume of the 'English Flora.' Since its publication the real structure of the hymenium has been ascertained, and consequently some improvements and alterations are requisite; a sketch of these has been given by the author of that volume in Dr. Lindley's 'Vegetable Kingdom,' and since its publication a long article has appeared on the subject in Orbigny's 'Dictionnaire d'Histoire Naturelle ' from the pen of M. Léveillé, agreeing in all essential points with Mr. Berkeley's arrangement, and this has been applied by Dr. Mougeot to an extensive series of fungi published in the statistical account of the Department des Vosges. It has been objected to both, perhaps with some justice, that they are founded solely on the fructification, without paying sufficient attention to morphology; it is however certain that the real affinities of the genera are more truly indicated than in any former arrangement, and we shall be rejoiced if the forthcoming morphological arrangement by Professor Fries in the 'Summa Vegetabilium Scandinaviæ' remedies acknowledged defects without creating new difficulties. We do not blame Mrs. Hussey therefore for adopting the arrangement of the 'English Flora' in preference to that in the 'Vegetable Kingdom,' in which indeed there are some manifest errors, her object being to refer students to the most readily available source of information.

Some excellent observations follow on collecting and examining fungi, which will be read with interest even by practised students; and the same may be said of the general accounts of the species illustrated, in which there is always something worth notice, either from its intrinsic value, or from being placed in a novel point of view. It is not indeed to be expected as regards a subject of such immense extent, and requiring access to a multitude of rare and expensive books, in various languages, that in a work whose merits rest 
expressly on faithfulness of execution and personal observation, there should not be here and there some little matter for criticism, but it will be found that with that nicety of tact which is so characteristic of her sex, Mrs. Hussey has avoided in general such difficulties.

Of the original drawings of Mrs. Hussey and her sister it is impossible to speak too highly; many of them are so exquisite as to be positively fit for public exhibition, and so characteristic that it is impossible not at once to recognise the species. These are reproduced faithfully by the lithographer, but there is a certain want of force about the lithographs which does not do justice to the originals. This and some other points connected with the editorial department will we doubt not be improved in the course of publication. Meanwhile we recommend the work most cordially to our readers, who will find accurate and beautiful illustration combined with much practical and interesting matter, especially as regards the culinary use of these neglected but by no means despicable objects.

\section{PROCEEDINGS OF LEARNED SOCIETIES.}

\section{ZOOLOGICAL SOCIETY.}

April 13, 1847.-Wm. Yarrell, Esq., Vice-President, in the Chair.

Notes on some rare Birds of New Zealand and Australia. By Mr. F. Strange, in a Letter to John Gould, Esq., F.R.S. etc.

" Strigops habroptilus, G. R. Gray.-The $K a-k a-p o$, or Night Parrot of the New Zealanders, is an inhabitant of the western side of the Middle island, and like the Kiwi-kiwi or Apteryx is strictly nocturnal in its habits, and never leaves its retreat during the day; its usual place of resort consists of burrows, formed by itself, beneath the roots of large trees or under immense pieces of rock, whence they cannot, even by the natives, be easily dug out. Its food consists of fern-roots, which it digs up with its bill, and the outer covering of the leaves of flax, which it obtains by drawing the leaves between the mandibles and leaving the flax behind. They are not gregarious, more than two never being found together, except a pair of young ones, which appear to stop with the old birds until they have attained the size of their parents. This is one of the birds the natives set great store by, the head being cut off, strung by the nostrils, and worn in the ears on their grand feast-days. It is known to the sealers by the name of the Green Bird of New Zealand.

"Apteryx Australis.-Kiwi-kiwi of the New Zealanders. I am told that a second species of Apteryx is to be found on the Middle island, that it stands about three feet high ; it is called by the sealers the Fireman. Aware, from your figures and description, that the sexes differ considerably in size, I pointed this out to my informant; but he still persisted that there are two species, in confirmation of which opinion he added, that he had taken the eggs of the two birds, 


\section{$2 \mathrm{BHL}$ Biodiversity Heritage Library}

1847. "Illustrations of British Mycology. By Mrs. T. I. Hussey. Reeve, Brothers. 4to. Parts 1 \& 2." The Annals and magazine of natural history; zoology, botany, and geology 20, 54-55. https://doi.org/10.1080/037454809496013.

View This Item Online: https://www.biodiversitylibrary.org/item/19465

DOI: https://doi.org/10.1080/037454809496013

Permalink: https://www.biodiversitylibrary.org/partpdf/14194

\section{Holding Institution}

Natural History Museum Library, London

\section{Sponsored by}

Natural History Museum Library, London

\section{Copyright \& Reuse}

Copyright Status: Public domain. The BHL considers that this work is no longer under copyright protection.

This document was created from content at the Biodiversity Heritage Library, the world's largest open access digital library for biodiversity literature and archives. Visit BHL at https://www.biodiversitylibrary.org. 